\title{
Femoral to crural and distal-leg bypasses - five-year-period analysis in University Hospital Centre Zagreb
}

\author{
(D)Josip Figl*, \\ (i)Tomislav Meštrović, \\ (1)Ivan Brižić, \\ (DDamir Halužan, \\ (DDino Papeš, \\ (D) Predrag Pavić, \\ (D)Andrea Crkvenac \\ Gregorek, \\ DIrena Šnajdar, \\ (DIvan Škorak
}

University of Zagreb School of Medicine, University Hospital Centre Zagreb, Zagreb, Croatia

\begin{abstract}
KEYWORDS: critical limb ischemia, distal-leg bypass, femoral to crural bypass. CITATION: Cardiol Croat. 2021;16(1-2):70. | https://doi.org/10.15836/ccar2021.70
\end{abstract}

*ADDRESS FOR CORRESPONDENCE: Josip Figl, Klinički bolnički centar Zagreb, Kišpatićeva 12, HR-10000 Zagreb, Croatia. / Phone: +385-1-2388-240 / E-mail: figlmd@gmail.com

ORCID: Josip Figl, https://orcid.org/0000-0001-6755-8656 • Tomislav Meštrović, https://orcid.org/0000-0002-3492-3837 Ivan Brižić, https://orcid.org/0000-0002-5874-8666 • Damir Halužan, https://orcid.org/0000-0002-8587-8351 Dino Papeš, https://orcid.org/0000-0001-7241-9693 • Predrag Pavić, https://orcid.org/0000-0002-0117-7663 Andrea Crkvenac Gregorek, https://orcid.org/0000-0002-7790-1347 • Irena Šnajdar, https://orcid.org/0000-0002-4429-1095 Ivan Škorak, https://orcid.org/0000-0002-4900-4876

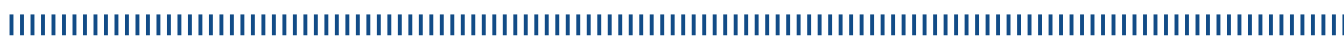

The goal: To compare the results of most distal femoral bypasses in our institution with results in literature.

Patients and Methods: A single centre retrospective analysis of femoral to crural and distal-leg bypass performed in University Hospital Centre Zagreb between 2014 and 2018.

Results: Primary one-year patency is even a bit better in our hospital than in literature (80\% vs $77 \%$ respectively) and secondary patency is in the range of the world literature (54\% vs $68 \%$ respectively).

Conclusion: Surgical revascularization in form of the most distal bypasses, performed in this institution observed, although reserved for a smaller number of patients, is very good and reliable method of treatment, and its results are at the level of world standards and percentages. ${ }^{1-3}$
RECEIVED:

November 13, 2020

ACCEPTED:

December 18, 2020

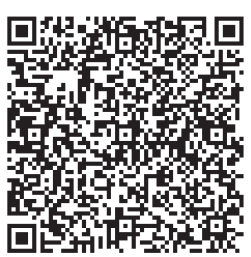

LITERATURE IIIIIIIIIIIIIIIIIIIIIIIIIIIIIIIIIIIIIIIIIIIIIIIIIIIIIIIIIIIIIIIIIIIIIIIIIIIIIIIIIIIIIIIIIIIIIIIIIII

1. Wölfle KD, Bruijnen H, Loeprecht H, Rümenapf G, Schweiger H, Grabitz K, et al. Graft patency and clinical outcome of femorodistal arterial reconstruction in diabetic and non-diabetic patients: results of a multicentre comparative analysis. Eur J Vasc Endovasc Surg. 2003 Mar;25(3):229-34. https://doi.org/10.1053/ejvs.2002.1849

2. van der Zaag ES, Legemate DA, Prins MH, Reekers JA, Jacobs MJ. Angioplasty or bypass for superficial femoral artery disease? A randomised controlled trial. Eur J Vasc Endovasc Surg. 2004 Aug;28(2):132-7. https://doi.org/10.1016/j.ejvs.2004.04.003

3. Veith FJ, Gupta SK, Ascer E, White-Flores S, Samson RH, Scher LA, Towne JB, Bernhard VM, Bonier P, Flinn WR, et al. Six-year prospective multicenter randomized comparison of autologous saphenous vein and expanded polytetrafluoroethylene grafts in infrainguinal arterial reconstructions. J Vasc Surg. 1986 Jan;3(1):104-14. https://doi.org/10.1016/0741-5214(86)90073-X 